INSIGHTS INTO REGIONAL DEVELOPMENT

ISSN 2669-0195 (online) http://jssidoi.org/IRD/

2021 Volume 3 Number 2 (June)

http://doi.org/10.9770/IRD.2021.3.2(3)

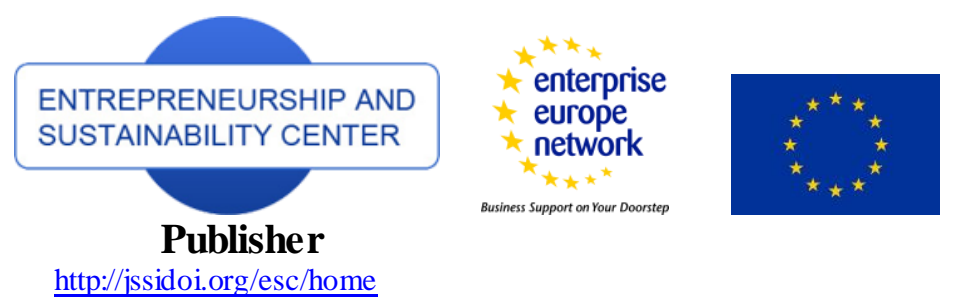

\title{
METHODOLOGY OF ANALYSIS OF THE INFLUENCE OF THE ECONOMIC POLICY OF THE STATE ON THE ENVIRONMENT*
}

\author{
Natalya Andryeyeva ', Oksana Nikishyna ${ }^{2}$, Borys Burkynskyi ${ }^{3}$, Nina Khumarova ${ }^{4}$, Oleksandr Laiko ${ }^{5}$, \\ Hanna Tiutiunnyk 6 \\ 1,2,3,4,5,6 Institute of Market Problems and Economic\&Ecological Research NAS of Ukraine, \\ 65044, French boulevard, 29, 65044 Odessa, Ukraine \\ E-mails: ${ }^{1} \underline{\text { andreevann@ukr.net, }},{ }^{2}$ ksenkych@gmail.com, ${ }^{3}$ Burkinskij@nas.gov.u, ${ }^{4}$ oss_iprei@ukr.net, ${ }^{5} \underline{\text { alexlayko@gmail.com }}$, \\ 6ecoregnaturres@ukr.net
}

Received 10 November 2020; accepted 10 March 2021; published 30 June 2021

\begin{abstract}
The methodological vision of the formation of the state economic policy, based on the needs of society sustainable development was proposed; the methodology for analyzing the impact of economic and environmental indicators of the implementation of the state economic policy, as an alternative to decoupling analysis was developed. Methodology. Methodological basis is formed by the convergence of four methodological approaches: methods of evaluation of indicators of "green" growth of the OECD; National System of Sustainable Development; methodological support for determining the economic and environmental priorities of "green" economy in the context of sustainable development; normative approach to the evaluation of parameters of economic safety of the state. Results. The proposed methodological support was approbated on the example of Ukraine in the period from 2010 to 2018. Practical approbation of the methodology allowed us to determine the cause-and-effect relationships between the dynamics of changes in economic and environmental indicators, positive and negative trends in the process of environmental transformation of economic policy. Value/originality. The original feature of the author's methodology is a logical and structural analysis of the main factors influencing the components of resource and environmental productivity of GDP and an extended diagnostic procedure.
\end{abstract}

Keywords : analysis; economic policy; environment; indicators; diagnostics; sustainable development

Reference to this paper should be made as follows: Andryeyeva, N., Nikishyna, O., Burkinskyi, B., Khumarova, N., Laiko, O., Tiutiunnyk, H.. 2021. Methodology of analysis of the influence of the economic policy of the state on the environment. Insights into the regional development, 3(2), 198-212. http://doi.org/10.9770/IRD.2021.3.2(3)

JEL Classifications: O12, O13, O44

Additional disciplines ecology and environment

\footnotetext{
* The research was performed within the Research work "Dominants of investment and innovation policy of nature management of the national economy "budget program" Support for the development of priority areas of research "(Code of the budget program 6541230), Ukraine
} 
INSIGHTS INTO REGIONAL DEVELOPMENT

ISSN 2669-0195 (online) http://jssidoi.org/jesi/

2021 Volume 3 Number 2 (June)

http://doi.org/10.9770/IRD.2021.3.2(3)

\section{Introduction}

The public view of the economic development of the world community is currently actively associated with the international paradigm of sustainable development. Sustainability should be viewed as humanity's target goal of human-ecosystem equilibrium, while 'sustainable development' refers to the holistic approach and temporal processes that lead us to the endpoint of sustainability (Richard Ross, 2015). The concept of sustainable development has developed beyond the initial intergenerational framework to focus more on the goal of "socially inclusive and environmentally sustainable economic growth" (Sachs, Jeffrey D. 2015). The global economic growth generates an increase in the extraction and consumption of natural resources, increasing the degree of negative impact on the environment. Currently, the task of studying the possibilities of economic growth without increasing the natural capacity of economic systems and reducing environmental damage from economic activities is of particular relevance. The world's strategic development guidelines are reflected in the 17 Sustainable Development Goals, which focuses on strengthening the means of implementation and revitalization of global partnership for sustainable development (Goal 17, 2020).

Sustainable development is a major global objective to overcome the economic, environmental and societal crises in many countries. In the last 30 years, the concept of sustainable development has taken shape thanks to a greater awareness of the need for sustainable development. Various public Institutions at international and national levels (e.g. International Organization, National Public Administration, Municipality, and University) played a key role. Sustainability is defined as the practice of maintaining world processes of productivity indefinitely - natural or human-made by replacing resources used with resources of equal or greater value without degrading or endangering natural biotic systems (Lynn R. Kahle, Eda Gurel-Atay, Eds., 2014). One of the main instruments to develop a smart, sustainable and integrated growth (European Commission, 2010) is through the circular economy (European Commission, 2014, Pardo, P. \& Schweitzer, J.P., 2018; Stankevičius A, Novikovas A., Bakaveckas A., \& Petryshyn O., 2020). Furthermore, it is important to promote a sustainable behavior (Goal of the Sustainable Development Goals) specifically on sensitive issues such as social and environmental responsibility, so that all citizens can acquire and develop skills needed to promote the goals of the Agenda 2030 (United Nations, 2015, Barbier, E., 1987).

The purpose of the article is to form the methodology and develop the methods for analyzing the impact of economic indicators on the environmental condition of the state and their approbation at the state level. There is a large discussion among the international scientific communities about the complexity of making management decisions considering social, environmental, and investment and innovation factors. In this issue, it is very important, firstly, to ensure the combination of society, science, business and government, and secondly, to consider the existing natural and resource potential of territories and existing natural capital, as well as to determine the level of environmental pollution.

Events, especially large-scale ones, produce several impacts on a territory, which are not exclusively economic in nature. The evaluation of the environmental and social effects of an event is very complex, not only because the effects are often indirect and intangible, and, therefore, difficult to perceive and measure in time, but also because the variables which affect the outcomes are manifold in reality. Moreover, because of the wide range of the goals pursued and of the heterogeneity of the subjects involved both directly and indirectly (stakeholders), it is extremely difficult to single out the parameters by which to measure the success of an event. In fact, several scholars have stated that these performance measures differ according to the subjects involved in the evaluation (promoters, organisers, communities and sponsors) and the goals pursued (Bowdin, G., Allen, J., O'Toole, W. G., Harris, R. \& McDonnell, I., 2011, Carayannis, E. G. \& Campbell, D. F. J., 2010; Mirzayeva, G., Turkay, O., Akbulaev, N., \& Ahmadov, F. 2020). 
INSIGHTS INTO REGIONAL DEVELOPMENT

ISSN 2669-0195 (online) http://jssidoi.org/jesi/

2021 Volume 3 Number 2 (June)

http://doi.org/10.9770/IRD.2021.3.2(3)

However, as for making managerial decisions at the state level, it is very important to form the balanced algorithm of actions, which is formed on the basis of an in-depth analysis of economic and environmental indicators (O'Sullivan, Arthur \& Sheffrin, Steven M., 2003). In economic theory, the scientists have developed a number of concepts of the relationship between economic growth and environmental pressure, in particular, the concepts of dematerialization, environmental efficiency, environmental competitiveness, and so on. The concept of decoupling as a phenomenon of the gap between economic development and the degree of anthropogenic impact on the natural environment has become the most widespread in recent years. In the field of environmentaleconomic research, decoupling refers to the direction that could allow the economy to grow without a corresponding increase in pressure on the environment. Currently, in many countries, increased production is increasing the burden on the environment. An economy that supports economic growth while reducing the amount of resources used, such as water or fossil fuels, while not linking environmental degradation would be said to be decoupled (Decoupling Natural Resource Use and Environmental Impacts from Economic Growth, 2020). Relative decoupling refers to a decline in the ecological intensity per unit of economic output. Absolute decoupling refers to a situation in which resource impacts decline in absolute terms (Jackson, Tim, 2009). At the same time, the implementation of economic and environmental priorities of the state in the practical plane makes it necessary to develop new methodological approaches to the analysis of the transformational impact of economic indicators on the environment conditions in the state (Smith, Charles Emrys, 2009). Despite the existing methodological developments, there is a need for new approaches to the multidimensional study of the relationship between economic growth, destructive impact on the environment and the use of natural resources, with an emphasis on the diagnosis of economic and environmental indicators, as well as the assessment of many factors as an alternative to decoupling analysis (Sachs, Jeffrey D., 2015). These circumstances determined the purpose and objectives of this study.

\section{Results}

The methodology for calculating GDP productivity indicators provides for the use of three GDP indicators (see table. 1). For calculating specific indicators (per 1 person), the dynamics of the population of Ukraine is important. The values of these indicators and their basic indexes (compared to 2010) are shown in table 2. Attention is drawn to the significant difference between the basic GDP indexes in actual and comparable prices in 2010, which is a consequence of inflationary influence. Thus, in 2018, compared to 2010, the GDP index in actual prices was $329.7 \%$, in comparable prices in $2010-96.7 \%$. In other words, in comparable prices, there is a downward trend in GDP in the period from 2014 to 2018, which is due, in particular, to a decrease in the statistical sample of data from the temporarily occupied territories.

Table 1. Methodology and methodological support for the analysis of the impact of economic indicators of state economic development on the environment

\begin{tabular}{|c|c|}
\hline 1. Goal & $\begin{array}{l}\text { Measuring the progress of "green" growth by determining the level and dynamics of the interaction of economic } \\
\text { and environmental indicators, as a methodological basis for developing mechanisms for managing economic } \\
\text { relations in the context of the international paradigm of sustainable development }\end{array}$ \\
\hline 2. Task & $\begin{array}{l}\text { 1. Systematization of information flows in terms of the main areas of evaluation } \\
\text { 2. Assessment of the state and dynamics of the components of the basic indicator } \\
\text { 3. Assessment of the state and dynamics of factors influencing the components of the basic indicator } \\
\text { 4. Generalized evaluation of the results of the analysis as a basis for making managerial decisions on the } \\
\text { mechanisms of sustainable development } \\
\text { 5. Forecasting the dynamics of indicators of resource and environmental productivity of GDP }\end{array}$ \\
\hline 3. Principles & $\begin{array}{l}\text { 1. Systematic 3. Effectiveness } \\
\text { 2. Objectivity and accuracy 4. Scientific and flexible }\end{array}$ \\
\hline 4. Methodical basis & $\begin{array}{l}\text { 1. OECD methodology - indicators of "green" growth of the OECD (a group of indicators of environmental and } \\
\text { resource efficiency) } \\
\text { 2. Methodology for assessing the Sustainable Development Goals, adapted for Ukraine } \\
\text { 3. Methodological support for determining the economic and environmental priorities of the "green economy" in } \\
\text { the context of sustainable development of Ukraine } \\
\text { 4. Normative assessment of the parameters of economic security of the state }\end{array}$ \\
\hline
\end{tabular}


INSIGHTS INTO REGIONAL DEVELOPMENT

ISSN 2669-0195 (online) http://jssidoi.org/jesi/

2021 Volume 3 Number 2 (June)

http://doi.org/10.9770/IRD.2021.3.2(3)

Continuation of the table 1.

\begin{tabular}{|c|c|}
\hline $\begin{array}{l}\text { Indicators of } \\
\text { resource and } \\
\text { environmental } \\
\text { productivity of } \\
\text { GDP }\end{array}$ & $\begin{array}{l}\text { 1. Indicators for estimating the amount of consumed resource (resource factors): } \\
\text { 1.1. Water productivity (capacity) of GDP } \\
\text { 1.2. Energy productivity (capacity) of GDP } \\
\text { 2. Indicators for environmental impact assessment (environmental factors): } \\
\text { 2.1. Carbon productivity (capacity) of GDP } \\
\text { 2.2. Productivity of GDP by waste }\end{array}$ \\
\hline $\begin{array}{l}\text { 6. Components of } \\
\text { GDP performance } \\
\text { indicators }\end{array}$ & $\begin{array}{l}\text { 1. GDP in actual, constant prices, constant prices in } 2011 \text { for PKS } \\
\text { 2. Volumes of water consumption; volumes of water abstracted from natural water bodies. } \\
\text { 3. Final energy consumption; general supply of primary energy } \\
\text { 4. Carbon dioxide emissions } \\
\text { 5. Volumes of generated waste of I-IV classes; }\end{array}$ \\
\hline $\begin{array}{l}7 . \quad \text { Factors } \\
\text { influencing the } \\
\text { components of } \\
\text { GDP productivity }\end{array}$ & $\begin{array}{l}\text { 1. Structural transformations of gross value added } \\
\text { 2. Production volumes in sectors of the national economy } \\
\text { 3. Average annual population } \\
\text { 4. The amount of costs for environmental protection (capital investment and current costs) } \\
\text { 5. Structural changes in environmental investment }\end{array}$ \\
\hline $\begin{array}{l}\text { 8. Evaluation } \\
\text { procedure }\end{array}$ & $\begin{array}{l}\text { 1. Analysis of indicators of economic development of the country in the context of economic security parameters } \\
\text { 2. Assessment of the dynamics of factors influencing the components of GDP productivity indicators } \\
\text { 4. Assessment of the level and dynamics of water productivity and water capacity of GDP } \\
\text { 5. Assessment of the level and dynamics of energy productivity and energy intensity of GDP } \\
\text { 6. Assessment of the state and dynamics of carbon productivity and GDP capacity } \\
\text { 7. Assessment of the state and dynamics of productivity and GDP capacity by waste } \\
\text { 8. Assessment of the impact of agriculture and raw material exports on the state of the environment } \\
\text { 9. Generalized diagnosis of the impact of economic indicators on sustainable development of the state and the } \\
\text { environment }\end{array}$ \\
\hline
\end{tabular}

Source: authorial development

This reason led to a sharp decline in the population index from $99.2 \%$ in 2013 to $93.7 \%$ in 2014, which should be considered when analyzing the interaction of economic and environmental indicators. The volume of output in national economic sectors is an important factor influencing the components of GDP productivity

Table 2. Values and basic indices of GDP and population in Ukraine

\begin{tabular}{|c|c|c|c|c|c|c|c|c|}
\hline \multirow{2}{*}{ Indicators } & \multicolumn{8}{|l|}{ Years } \\
\hline & 2010 & 2012 & 2013 & 2014 & 2015 & 2016 & 2017 & 2018 \\
\hline $\begin{array}{l}\text { 1. GDP at actual } \\
\text { prices, UAH billion }\end{array}$ & 1079,35 & 1404,67 & 1465,20 & 1586,92 & 1988,54 & 2385,37 & 2983,88 & 3558,71 \\
\hline$\%$ to 2010. & 100,0 & 130,1 & 135,7 & 147,0 & 184,2 & 221,0 & 276,5 & 329,7 \\
\hline $\begin{array}{l}\text { 2. GDP at constant } \\
\text { prices in } 2010, \mathrm{UAH} \\
\text { billion }\end{array}$ & 1079,35 & 1141,06 & 1140,75 & 1066,00 & 961,82 & 985,30 & 1009,60 & 1043,27 \\
\hline$\%$ to 2010 & 100,0 & 105,7 & 105,7 & 98,8 & 89,1 & 91,3 & 93,5 & 96,7 \\
\hline & 2010 & 2012 & 2013 & 2014 & 2015 & 2016 & 2017 & 2018 \\
\hline $\begin{array}{l}\text { 3. GDP at constant } \\
2011 \text { prices for PKS, } \\
\text { billion int. dollars }\end{array}$ & 358,92 & 379,44 & 379,33 & 354,48 & 319,49 & 327,22 & 335,4 & 346,9 \\
\hline$\%$ to 2010 & 100,0 & 105,7 & 105,7 & 98,8 & 89,0 & 91,2 & 93,4 & 96,7 \\
\hline $\begin{array}{ll}\text { 4. Average } & \text { annual } \\
\text { population, } & \text { million } \\
\text { people } & \\
\end{array}$ & 45,87 & 45,59 & 45,49 & 43,00 & 42,84 & 42,67 & 42,49 & 42,27 \\
\hline$\%$ to 2010 & 100,0 & 99,4 & 99,2 & 93,7 & 93,4 & 93,0 & 92,6 & 92,1 \\
\hline
\end{tabular}

Source: calculated by the authors according to the State Statistics Service of Ukraine (Report on Green Transformation in Ukraine based on OECD Green Growth Indicators, 2016, Sustainable Development Goals: Ukraine: National Report, 2017, Statistical Yearbook of Ukraine for 2018). 
INSIGHTS INTO REGIONAL DEVELOPMENT

ISSN 2669-0195 (online) http://jssidoi.org/jesi/

2021 Volume 3 Number 2 (June)

http://doi.org/10.9770/IRD.2021.3.2(3)

Some idea of their dynamics is provided by statistical data on the dynamics of product indexes, in particular in industry, construction and agriculture (Table 3).

Table 3. Dynamics of indices of industrial, construction and agricultural products in Ukraine, $\%$ to the previous year

\begin{tabular}{|c|c|c|c|c|c|c|c|c|}
\hline Indicators & \multicolumn{8}{|c|}{ Years } \\
\hline 1.1. Mining and quarrying & 104,5 & 101,9 & 100,6 & 86,3 & 85,8 & 99,8 & 94,3 & 102,4 \\
\hline 2. Indices of construction products & n.d. & 91,7 & 88,9 & 79,6 & 87,7 & 117,4 & 126,3 & 108,5 \\
\hline 3. Agricultural production indices & 98,6 & 96,1 & 113,6 & 102,2 & 95,2 & 106,3 & 97,8 & 108,1 \\
\hline
\end{tabular}

Source: Calculated by the authors according to the State Statistics Service of Ukraine (Statistical Yearbook of Ukraine for 2018).

In 2014-2015, there was a decrease in the level of industrial production indexes, including in the mining and processing industries, as the main consumers of resources, which affects the level of the GDP productivity indicator for this period. For agriculture in the period from 2013 to 2014, there is a tendency to increase production (by $13.6 \%$ and 2.2\%), which in 2015 changes to the opposite. The dynamics of production indexes should be considered when evaluating indicators of resource and environmental productivity of GDP, because resources treated as important economic assets (Barbier, Edward B., 2006). Another important factor affecting the productivity components of GDP is the amount spent on environmental protection (see table. 1). According to statistics, in 2018, total expenditures on environmental protection in Ukraine amounted to UAH 34.39 billion. (in actual prices), an increase of $162 \%$ over the 2010 baseline. During the study period, the volume of environmental investment varied from $1.5 \%$ of GDP in 2012 to $1.0 \%$ of GDP in 2018. At the same time, the growth of the indicator in actual prices was accompanied by a decrease in its share in GDP from 1.2 to $1 \%$ (Richards, G. \& Palmer, R., 2010). In 2010-2018, there were structural changes in the composition of expenditures on environmental protection: the share of capital investments increased from $21 \%$ to $29 \%$, while the share of current expenditures, on the contrary, decreased from $79 \%$ to $71 \%$, respectively. The dynamics of capital expenditures and current expenditures on environmental protection in Ukraine is clearly shown in fig. 1.

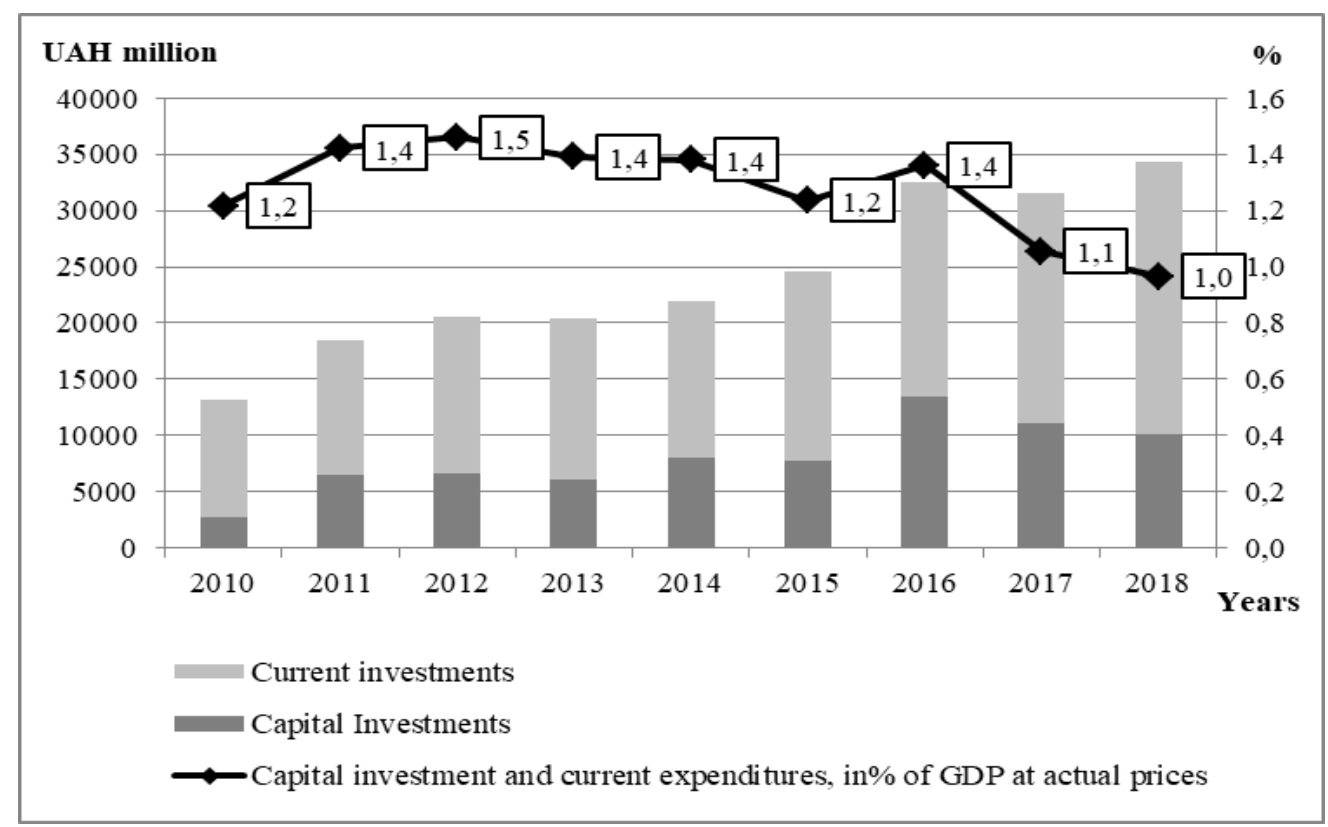

Fig. 1. Capital investments and current expenditures for environmental protection in Ukraine, UAH million and\% of GDP Source: built by the authors according to the State Statistics Service of Ukraine (Report on Green Transformation in Ukraine based on OECD Green Growth Indicators, 2016, Sustainable Development Goals: Ukraine: National Report, 2017). 
INSIGHTS INTO REGIONAL DEVELOPMENT

ISSN 2669-0195 (online) http://jssidoi.org/jesi/

2021 Volume 3 Number 2 (June)

http://doi.org/10.9770/IRD.2021.3.2(3)

In $2018,86.9 \%$ of expenditures on environmental protection were made up of own funds of enterprises and organizations, $6.7 \%$ - the state and local budgets, and $6.4 \%$ - other sources of financing. In 2018, by structure, the largest share of capital investments was directed mainly to atmospheric air protection (34.8\%), radiation safety $(20.2 \%)$, and wastewater treatment $(16.8 \%)$ (table 4$)$. During the reporting period, the structure of current expenditures was dominated by the expenditures on wastewater treatment (39.6\%) and waste management $(36.3 \%)$.

Table 4. Structure of capital investments and current expenditures for environmental protection in Ukraine, $\% *$

\begin{tabular}{|l|l|l|l|l|l|l|}
\hline \multirow{2}{*}{ Environmental protection measures } & \multicolumn{2}{|l|}{ Capital Investments } & \multicolumn{2}{l|}{ Current investments } \\
\cline { 2 - 6 } & Years $\begin{array}{l}\text { Changes } \\
(+,-)\end{array}$ & \multicolumn{2}{l|}{ Years } \\
\cline { 2 - 6 } & $\mathbf{2 0 1 0}$ & $\mathbf{2 0 1 8}$ & $\mathbf{2 0 1 0}$ & $\mathbf{2 0 1 8}$ \\
\hline $\begin{array}{l}\text { 1. Atmospheric air protection and climate change } \\
\text { issues }\end{array}$ & 41,2 & 34,8 & $-6,4$ & 12,7 & 11,9 \\
\hline 2. Return water treatment & 26,6 & 16,8 & $-9,8$ & 48,6 & 39,6 & $-0,8$ \\
\hline 3. Waste management & 17,2 & 11,7 & $-5,5$ & 25,1 & 36,3 \\
\hline $\begin{array}{l}\text { 4. Protection and rehabilitation of soil, groundwater } \\
\text { and surface water }\end{array}$ & 11,6 & 14,4 & $+2,8$ & 4,6 & 5,3 & $+11,2$ \\
\hline 5. Reduction of noise and vibration & 0,4 & 0,6 & $+0,2$ & 0 & 0,9 & $+0,7$ \\
\hline 6. Conservation of biodiversity and habitat & 0,7 & 0,7 & - & 2,3 & 3,3 \\
\hline 7. Radiation safety & 0,1 & 20,2 & $+20,1$ & 4,4 & 0,5 \\
\hline $\begin{array}{l}\text { 8. Research work } \\
\text { environmental orientation }\end{array}$ & 0,3 & 0,1 & $-0,2$ & 0,5 & $-3,9$ \\
\hline 9. Other types of environmental activities & 1,9 & 0,7 & $-1,2$ & 1,8 & 0,5 \\
\hline Total: & $\mathbf{1 0 0}$ & $\mathbf{1 0 0}$ & $\mathbf{X}$ & $\mathbf{1 0 0}$ & $\mathbf{1 0 0}$ \\
\hline
\end{tabular}

Source: calculated by the authors according to the State Statistics Service of Ukraine

Analyzing the structural changes in environmental investments, we can state that the priorities of the state's environmental policy have changed in the direction of implementing measures to ensure radiation safety, wastewater treatment, and waste management, which, of course, has affected the indicators of GDP productivity for water resources and waste. Environmental policy is used to influence human activities in order to prevent unwanted impacts on natural resources and the environment. It is also designed to ensure that changes in the environment do not have unacceptable consequences for humans (McCormick, John, 2001). The procedure for assessing the GDP resource productivity will be considered in detail on the example of water productivity of GDP in Ukraine, and environmental productivity - on the example of GDP productivity for waste. A group of indicators that characterize water productivity and water capacity of GDP in Ukraine is shown in table 5.

Table 5. Dynamics of indicators of water capacity and water productivity of GDP in Ukraine *

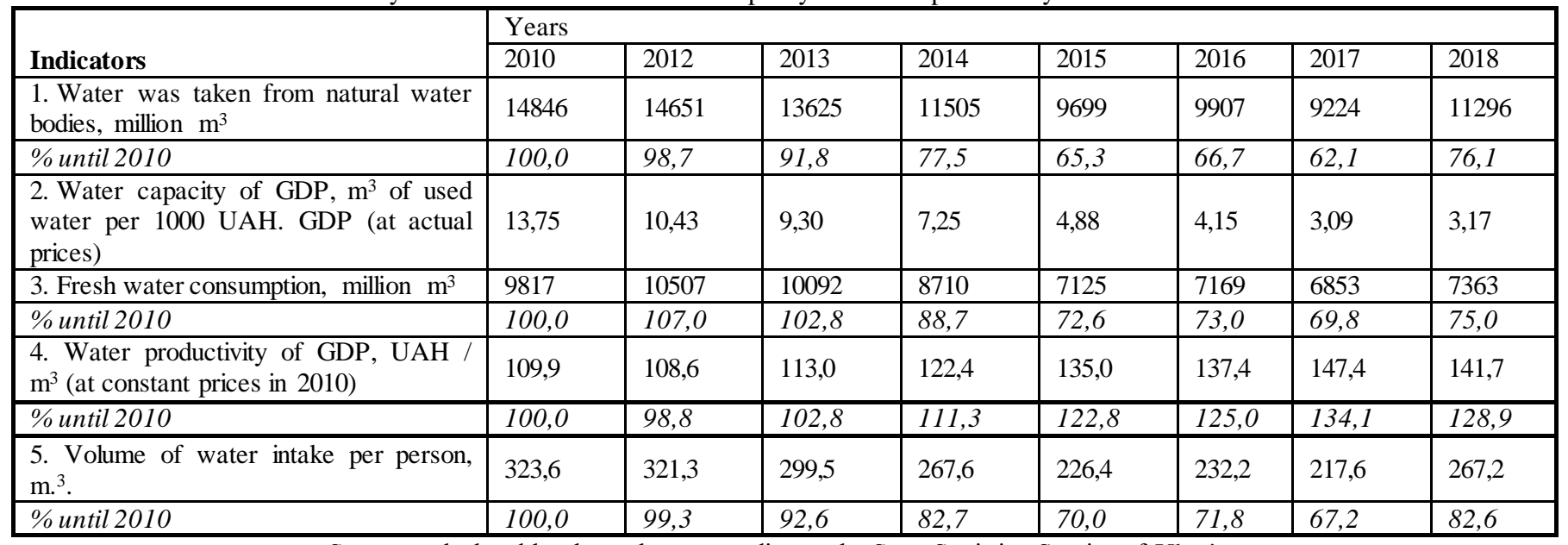


INSIGHTS INTO REGIONAL DEVELOPMENT

ISSN 2669-0195 (online) http://jssidoi.org/jesi/

2021 Volume 3 Number 2 (June)

http://doi.org/10.9770/IRD.2021.3.2(3)

Over the period from 2010 to 2018, the water capacity of GDP in Ukraine decreased by 4.3 times: from $13.75 \mathrm{~m}^{3}$ per thousand UAH of GDP up to $3.17 \mathrm{~m}^{3}$ per thousand UAH of GDP, reaching the target value of $2020\left(3.2 \mathrm{~m}^{3}\right.$ per thousand UAH of GDP). The tendency to decrease the water capacity of GDP was caused by a decrease in the volume of water taken from natural water bodies (in 2018, the base index was 76.1\%), while the GDP indicator in actual prices increased. In 2018, a significant increase in the volume of water taken (by $22.5 \%$ compared to the previous year) caused the growth of the indicator of water capacity of GDP by $0.08 \mathrm{~m}^{3}$ per thousand UAH of GDP.

Water productivity of GDP (in constant prices in 2010) increased from UAH $109.9 / \mathrm{m}^{3}$ in 2010 to UAH $141.7 / \mathrm{m}^{3}$ in 2018. The dynamics of water productivity of GDP was influenced by the following factors:

1) in 2011 and 2013, the GDP growth rate in constant prices of 2010 exceeded the growth rate of fresh water consumption, which provided the indicator value at the level of UAH $113 / \mathrm{m}^{3}$; in 2012, the opposite ratio was observed; 2) in 2014, a 10.1\% drop in industrial production as a result of military aggression in Eastern Ukraine and the partial loss of CIS markets led to a decrease in water consumption and an active increase in water productivity of GDP; 3) in the period from 2014 to 2018, the rate of reduction in water consumption (25\% in 2018) was consistently higher than the rate of decline in the GDP indicator in constant prices of 2010 (3.3\% in the reporting year), which led to a growing trend in GDP productivity in Ukraine (see fig. 2).

2)

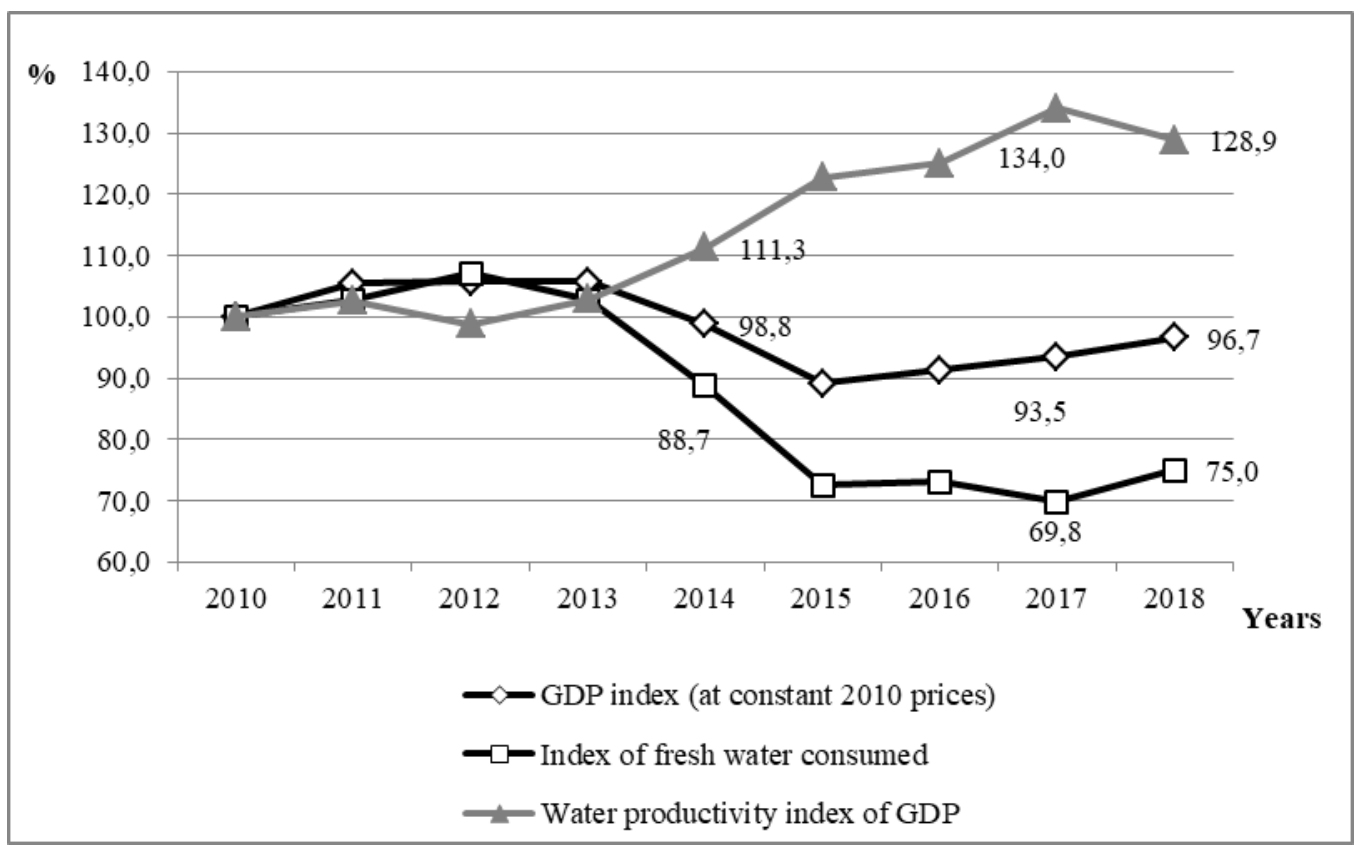

Fig. 2. Dynamics of basic indices of GDP, fresh water consumption and water productivity of GDP in Ukraine (in\% until 2010) Source: built by the authors

The current trend was reinforced by a drop in industrial production in the country - by $10.1 \%$ in 2014 and by $13 \%$ in 2015 compared to the previous year (see table 3). Since industry is the main consumer of water (43\% in 2016), the decrease in industrial output in the country was the main factor in reducing water capacity and, consequently, increasing the water productivity of GDP during the study period. A less noticeable impact on the dynamics of these indicators was a decrease in the volume of agricultural products (by $4.8 \%$ in 2015 and by $2.2 \%$ in 2017 compared to the previous year). Agriculture is the second largest consumer of water (32\% in 2016). The concept of sustainable agriculture extends intergenerationally, passing on a conserved or improved natural resource, biotic, and economic base rather than one which has been depleted or polluted. 
INSIGHTS INTO REGIONAL DEVELOPMENT

ISSN 2669-0195 (online) http://jssidoi.org/jesi/

2021 Volume 3 Number 2 (June)

http://doi.org/10.9770/IRD.2021.3.2(3)

The decrease in water consumption and increase in water productivity in Ukraine was influenced by the decrease in the population (by $7.9 \%$ compared to 2010), a drop in economic activity and industrial production, and more economical use of water due to the widespread use of water meters. In general, in the reporting year, the volume of water intake per 1 person in Ukraine reached $267.2 \mathrm{~m}^{3}$, decreasing by $17.4 \%$ compared to 2010 (see table 5).

Over the period from 2010 to 2018, the rate of reduction in the volume of discharges of polluted wastewater into water bodies was higher than the rate of reduction in the capacity of treatment facilities in Ukraine. Thus, in 2018, compared to 2010, the amount of discharges of polluted wastewater decreased by $45.4 \%$ against the background of a reduction in the capacity of treatment facilities by $27.6 \%$, which is a positive moment (Sustainable Development Goals: Ukraine: National Report, 2017). The positive trend of reducing the volume of discharges of polluted wastewater into water bodies in Ukraine is evidence of the gradual introduction of priorities for rational nature management. According to the indicator "wastewater treatment" in the rating of the Environmental Performance Index of 2018, Ukraine received a fairly high rating - 78.76 points (69th place out of 180 countries) (Report on Green Transformation in Ukraine based on OECD Green Growth Indicators, 2016). Therefore, we can speak about the positive impact of environmental investments on the state's water resources. A group of indicators that characterize the waste productivity and waste intensity of GDP in Ukraine is shown in table 6.

During the study period, the dynamics of the indicator of waste productivity of GDP in Ukraine is unstable, characterized by periods of decline (2012) and significant growth (by $31.4 \%$ in 2016). In 2018, the indicator value reached UAH 2961/ ton (in constant prices in 2010), increasing by $16.8 \%$ compared to 2010 (see fig. 3).

Table 6. Dynamics of indicators waste productivity and waste capacity of GDP in Ukraine*

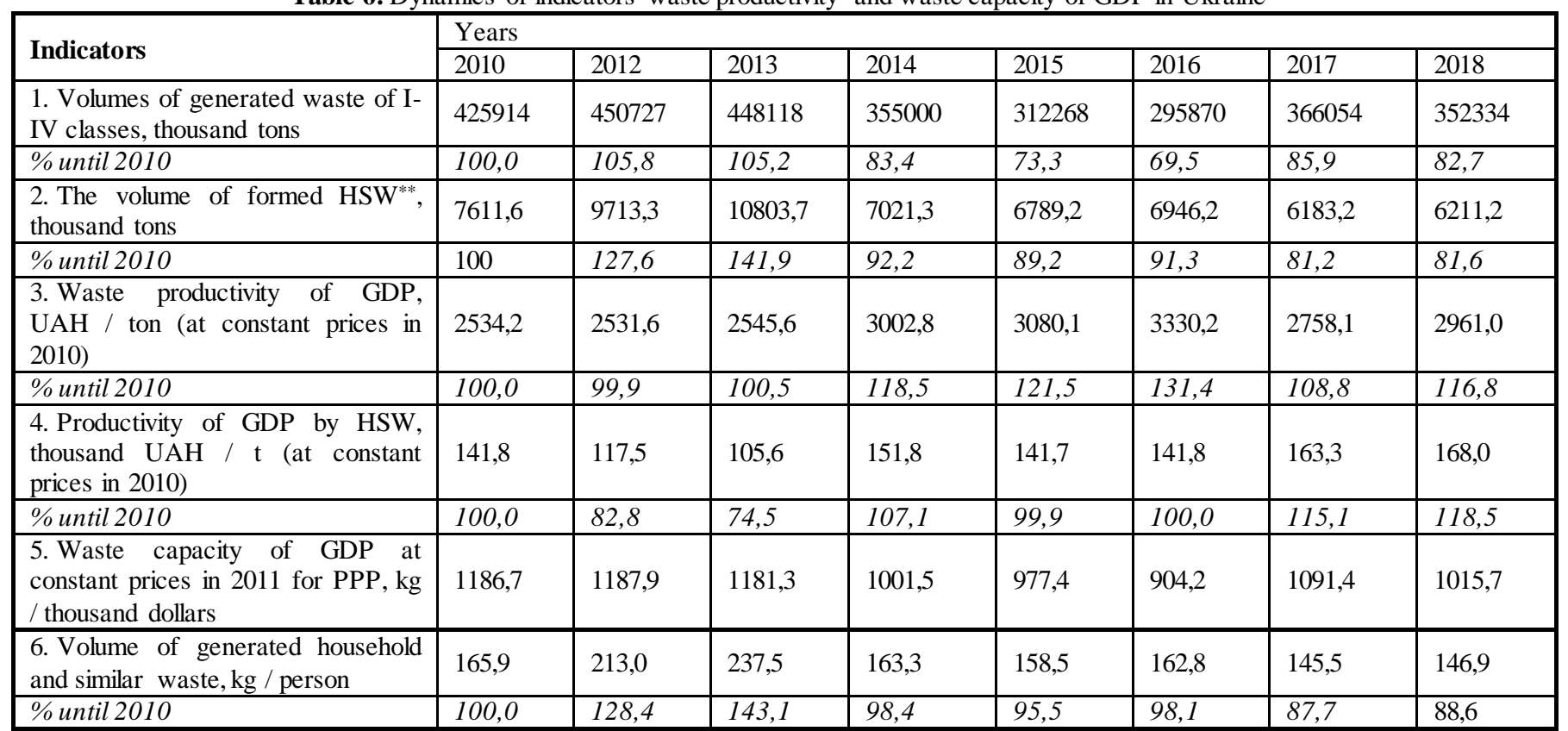

Source: Calculated by the authors according to the State Statistics Service of Ukraine (Report on Green Transformation in Ukraine based on OECD Green Growth Indicators, 2016, Sustainable Development Goals: Ukraine: National Report, 2017, Statistical Yearbook of Ukraine for 2018);

** HSW - household and similar waste.

The changes in the waste productivity of GDP over time can be divided into two periods:

1) the period from 2010 to 2013 is characterized by a slight increase in dynamics due to higher GDP growth rates in constant prices in 2010 compared to the growth rate of the volume of generated waste of the I-IV classes;

2) the period from 2014 to 2018 is characterized by the 10-20\% growth rate of the indicator due to the excess rate of waste reduction compared to the same indicator for GDP in constant prices in 2010. 


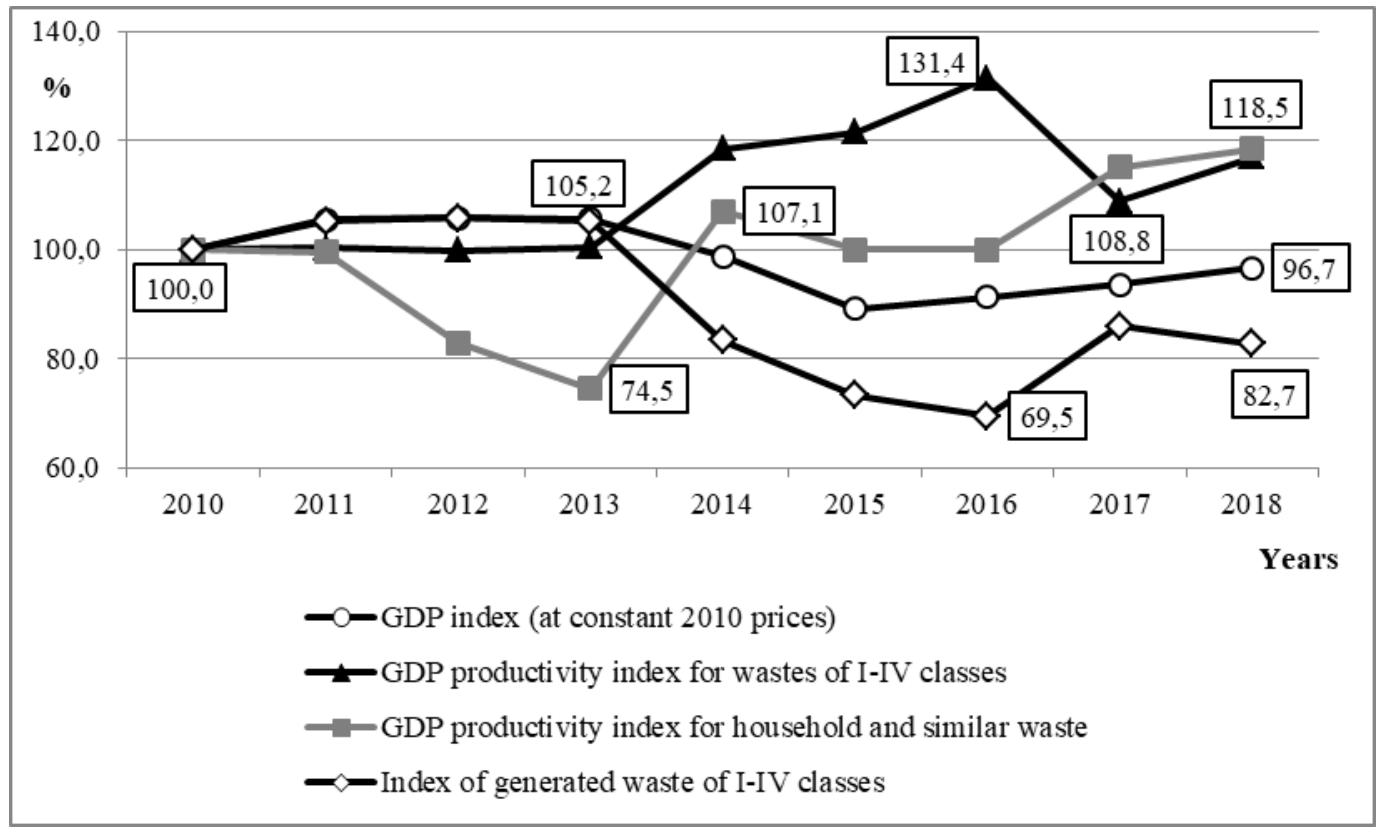

Fig. 3. Dynamics of GDP indices, generated wastes of I-IV classes and waste productivity of GDP in Ukraine, \% (2010 - 100\%)* Source: built by the authors

The main factor that caused the reduction of generated waste of the I-IV classes in Ukraine in 2014-2016 is the decrease in production volumes of the extractive industry and quarry development (see table 3), which generates more than $80 \%$ of the total generated waste in the country. In 2017, compared to 2010, the volume of waste from mining and quarrying decreased by $9.7 \%$, while compared to 2016, it increased by $32.1 \%$, which slightly slowed the growth in the level of waste productivity of GDP (from $31.4 \%$ to $8.9 \%$ ). The decrease in production volumes of the processing industry in 2012-2015 (see table 3), which generated about $10 \%$ of waste of the I-IV classes during this period, is also a significant factor in reducing their volumes in the country.

In 2018, the GDP productivity for household and similar waste (HSW) was UAH 168 thousand/t (in constant prices of 2010). The dynamics of the basic indexes of this indicator is quite variable, characterized by a significant reduction in 2013 to $74.5 \%$ and increase in 2018 to $118.5 \%$ (see fig. 3). In the reporting year, the excess of the rate of reduction in the volume of generated household and similar waste (18.4\%) over the rate of decline in GDP in constant prices in 2010 (3.3\%) caused the 18\% increase in GDP productivity for HSW in Ukraine (see table 4). A significant factor in the positive trend of reducing the amount of HSW in the state is the direction of a significant share of environmental investments to solve this problem. The share of investments in waste management in the structure of current expenditures increased from $25.1 \%$ in 2010 to $36.3 \%$ in 2018 , taking the second place among environmental measures (see table 4).

In 2018, UAH 1182.1 million capital investments were allocated for the implementation of waste management measures (2.1 times less than in 2016), including 96.1\% of funds were allocated for cleaning and 3.7\% - for integrated technologies. At the same time, in the reporting year, UAH 8830.2 million current expenditures were directed to waste management, which is three times higher than in 2010 . Of these, $75 \%$ of funds are spent on waste collection and transportation, and $16.7 \%$ - on waste treatment, disposal and destruction (Positions of Ukraine in the rating of environmental efficiency in 2018). 
INSIGHTS INTO REGIONAL DEVELOPMENT

ISSN 2669-0195 (online) http://jssidoi.org/jesi/

2021 Volume 3 Number 2 (June)

http://doi.org/10.9770/IRD.2021.3.2(3)

The allocation of a significant part of current expenditures to improve waste management contributed to the elimination in 2014 of unauthorized landfills formed due to incomplete coverage of the population of Ukraine with services for the collection and removal of household waste (Daly, H.E. (Ed.), 1980). This factor, together with the reduction in the population, caused the 35\% decrease in the volume of HSW in 2014 compared to 2013. At the same time, the volume of HSW per 1 person decreased by almost a half: from $237.5 \mathrm{~kg} /$ person in 2013 to $163.3 \mathrm{~kg} /$ person in 2014. In 2017, the indicator was $146.9 \mathrm{~kg} /$ person, decreasing by $11.4 \%$ compared to the 2010 baseline (see table 5).

In 2017, the level of waste intensity of GDP in constant prices in 2011 for the HSW amounted to 992.6 $\mathrm{kg}$ /thousand USD, an increase of $9.7 \%$ compared to 2016 , exceeding the 2020 target value $(950 \mathrm{~kg} /$ thousand USD) by $42.6 \mathrm{~kg} /$ thousand USD, due to a significant increase (24\%) in the volume of waste generated in 2017. Given the double reduction in the amount of capital investment in waste management, we should expect a continuation of the negative growth trend in the waste intensity of GDP in 2020.

\section{Discussion}

To assess the progress of "green" growth, the OECD methodology uses a group of environmental and resource productivity indicators that describe the key aspects of the transition to a low-carbon and resource-efficient economy (Xingrong Zhao, Xi Zhang, Ning Li, Shuai Shao \& Yong Geng, 2017, Yi Li, Jan Degener, Matthew Gaudreau, Yangfan Li \& Martin Kappas, 2016). In our opinion, a group of indicators of environmental and resource productivity of GDP can be used as the basis for the author's methodological approach (see table 1).

At the same time, we propose to supplement the calculation of the dynamics of basic indicators that are the results of the values of their structure-forming components (in particular, GDP and resource or environmental components) with an analysis of the factors that influence these components.

Such an extended assessment procedure, as a component of the Methodological recommendations, will allow us to identify many factors that influence GDP productivity indicators over a certain time period, to identify the main factors and problem areas in the progress of "green" growth, and mechanisms for overcoming them.

\section{Materials and Methods}

The main ideology of methodology and research methodology is to measure the progress of "green" growth by determining the level and dynamics of mutual influence of economic and environmental indicators, as a methodological basis for developing mechanisms for managing economic relations in the context of sustainable development of the state. The assessment of the impact of economic indicators on the main indicators of "green" growth in the state is based on a set of principles, to which the authors include the following: consistency; objectivity and accuracy; effectiveness; (scientificity and flexibility). The selected principles orient the research vector to assess the interaction of economic and environmental indicators taking into account all internal and external links between their components, main factors, the objectivity and accuracy of the information base and analytical calculations, the practical significance of the Methodological recommendations and their flexibility and adaptability to new changes in the economic and natural environment, their scientificity and openness to advanced methodological developments in the context of sustainable development.

The methodological basis of the recommendations (see table 1) is formed by the convergence of four methodological approaches: methods of evaluation of the indicators of "green" growth of the OECD; National System of Sustainable Development (Sustainable Development Goals: Ukraine: National Report, 2017); (3) methodological support for determining the economic and environmental priorities of "green" economy in the 
INSIGHTS INTO REGIONAL DEVELOPMENT

ISSN 2669-0195 (online) http://jssidoi.org/jesi/

2021 Volume 3 Number 2 (June)

http://doi.org/10.9770/IRD.2021.3.2(3)

context of sustainable development (Seneca, J.J., 1984); (4) normative approach to the estimation of parameters of economic safety of the state (Stavins, R., Wagner, A., Wagner, G., 2003).

The GDP performance indicators can be divided into 2 groups. The first group consists of the indicators for estimating the amount of resource consumed (resource productivity of GDP). The main ones are water and energy productivity of GDP. The second group is formed by the indicators for assessing the destructive impact on the environment (environmental productivity of GDP). The main ones are the carbon productivity of GDP and the waste productivity of GDP (see table 1). The ratio of GDP to the amount of the resources consumed (or pressure on the environment) determines the level of the indicator of resource (or environmental) productivity of GDP. The reverse is the GDP capacity indicator.

The main structural component of all productivity indicators is the volume of GDP, which is estimated in actual and constant prices, as well as constant prices in 2011 at purchasing power parity (PPP). In various combinations, these indicators are used to calculate the resource and environmental productivity of GDP, thus enabling their normative and cross-country comparison over a certain period of time. The second basic component of GDP productivity indicators is the amount of resource consumed (water, energy) and the level of environmental impact (carbon dioxide emissions, waste generated, etc.).

Among the main factors influencing the level of GDP, the authors highlight its structural transformations, in particular, changes in the sectoral structure of gross value added, and the dynamics of production volumes in the sectors of the national economy, which is manifested in the changes in product indexes (industrial, construction, agricultural, etc.). The main factors influencing the resource and environmental components of GDP productivity are the average annual population, the amount of environmental protection expenditures in terms of capital investment and current expenditures, and structural changes in environmental investment (see table 1). It should be noted that the group of factors in the Methodological recommendations can be expanded if there is a sufficient information base for their calculations.

The assessment procedure provides for the introduction of a step-by-step analysis of the impact of economic indicators of the state's economic development on the environmental condition (see table 1). It is proposed to start assessing the parameters of economic security of the state and the dynamics of indicators-factors of influence, since they directly or indirectly affect the components of all indicators of resource and environmental productivity of GDP, and then to detail the assessment in the context of these four basic indicators.

The analysis procedure involves comparing the actual values of GDP performance indicators, their components and impact indicators with the base period (2010), with the target values of indicators of 2020 for Ukraine, provided by the National Report (Sustainable Development Goals: Ukraine: National Report, 2017), with the values of indicators for the OECD member countries (interstate comparisons), the comparison of basic indexes of main and factor indicators, as well as the comparison of evaluation results with the components of the Environmental Efficiency Index of Ukraine of 2018 (Positions of Ukraine in the rating of environmental efficiency in 2018, 2019, Environmental Policies and Instruments, 2020).

The advantages of the proposed Methodological recommendations are the relative simplicity of indicators calculation (compared to the decoupling index), the analysis of not only the components of the basic indicator, but also a set of indicators that influence their level, which expands the analytical framework of the study, allowing both normative comparisons within the country and interstate comparison. The index of decoupling characterizes the relationship between its components, whereas the Methodological recommendations developed by the authors provide an in-depth logical and structural analysis of influence factors on the GDP resource and environmental productivity, allowing you to define original causes of changes, causal links and to substantiate the most effective tools for promoting "green" transformation of the economy (The History of Development, 2008). 
INSIGHTS INTO REGIONAL DEVELOPMENT

ISSN 2669-0195 (online) http://jssidoi.org/jesi/

2021 Volume 3 Number 2 (June)

http://doi.org/10.9770/IRD.2021.3.2(3)

\section{Conclusions}

In the course of the research the authors developed Methodological recommendations for assessing the impact of economic indicators on the state of rational nature management, which are based on many principles (systematicity, objectivity and accuracy, efficiency, scientificity and flexibility), convergence of European and national methodological approaches to environmental indicators evaluation procedure, which, in addition to assessing the level and dynamics of factors and indicators of GDP productivity, provides an analysis of economic security and the impact of agriculture and raw materials on the environment, which allows to deepen the analysis of socio-economic factors on the environment and "green" economy.

The assessment of the state and dynamics of the indicators of resource and environmental productivity of GDP in Ukraine allowed us to establish some general trends in their changes due to the influence of a number of factors. Thus, in the period from 2010 to 2018 there is a tendency of growth of all indicators of GDP productivity due to the combined effect of the following main factors: (1) the rate of reduction of GDP in constant prices (since 2014) is lower compared to the rate of reduction in resource use and environmental impact; (2) reduction in 2014 and 2015 of industrial production by $10.1 \%$ and 13\%; (3) structural transformation of gross value added; (4) reduction of volumes of discharges of polluted sewage into water objects, volumes of the generated wastes of the I-IV classes, including household and similar waste, due to the increased funding for environmental measures. A comparative analysis of the basic GDP productivity indexes shows the highest growth rates of water productivity $(28.9 \%)$ and the lowest - GDP productivity for waste (16.8\%).

The results of assessing the impact of economic indicators on the main indicators of "green" growth in Ukraine allowed us to identify positive and negative trends in the process of "green" transformation of the economy. Positive trends include the following: the growth of environmental protection expenditures (2.6 times); a significant increase in the indicators of water and carbon productivity of GDP (base indexes of $129 \%$ and 126\%, respectively); a decrease in the volume of discharges of polluted wastewater into water bodies; a stable increase in the area of organic land. Negative trends in the progress of "green" growth include the following: deviations of most parameters of economic security from the normative values; low level of energy productivity of GDP, according to which Ukraine is at the end of the rating of European countries; growth in the volume of waste of the I-V classes in 2017 compared to the previous year by $24 \%$ and the growth of the waste intensity of GDP; growth of raw material exports.

In general, the growth trend of all indicators of resource and environmental productivity of GDP in Ukraine in the period from 2010 to 2018 is due to the complex interaction of positive and negative changes in indicatorsfactors. Positive changes include the growth of environmental investments and their structural transformations, while negative changes include a reduction in production volumes in the sectoral dimension and the population of Ukraine.

\section{References}

A European strategy for smart, sustainable and inclusive growth 2010. European Commission. Retrieved from https://ec.europa.eu/eu2020/pdf/COMPLET\%20EN\%20BARROSO\%20\%20\%20007\%20-\%20Europe\%202020\%20-

$\% 20 \mathrm{EN} \% 20 \mathrm{version} . \mathrm{pdf}$

Barbier, E. 1987. The Concept of Sustainable Economic Development. Environmental Conservation, 14 (2), $101-110$. https://doi.org/10.1017/S0376892900011449 
INSIGHTS INTO REGIONAL DEVELOPMENT

ISSN 2669-0195 (online) http://jssidoi.org/jesi/

2021 Volume 3 Number 2 (June)

http://doi.org/10.9770/IRD.2021.3.2(3)

Barbier, Edward B. 2006. Natural Resources and Economic Development, pp. 44-45 Retrieved from https://books.google.com/books?id=fYrEDA-VnyUC\&pg=PA45

Bowdin, G., Allen, J., O’Toole, W. G., Harris, R. \& McDonnell, I. 2011. Events management. Retrieved from https://doi.org/10.4324/9780080964317

Carayannis, E. G. \& Campbell, D. F. J. 2010. Triple helix, quadruple helix and quintuple helix and how do knowledge innovation and the environment relate to each other? A proposed framework for a trans-disciplinary analysis of sustainable development and social ecology. International Journal of Social Ecology and Sustainable Development, 1(1), 41-69. Retrieved from https://doi.org/10.4018/jsesd.2010010105

Daly, H.E. (Ed.) 1980, Economy, Ecology, Ethics: Essays toward a Steady State Economy, Freeman, San Francisco, 38-43.

Decoupling Natural Resource Use and Environmental Impacts from Economic Growth, Summary for policymakers. Retrieved from https://www.resourcepanel.org/reports/decoupling-natural-resource-use-and-environmental-impacts-economic-growth (last accessed $02.10 .2020)$

Environmental Policies and Instruments. Retrieved from http://www.oecd.org/department/0,3355,en_2649_34281_1_1_1_1_1,00.html

Goal 17. Department of Economic and Social Affairs. Retrieved from http://sdgs.un.org

Jackson, Tim 2009. Prosperity without Growth: Economics for a Finite Planet (1 ed.). London: Earthscan. 67-71.

Lynn R. Kahle, Eda Gurel-Atay, Eds 2014. Communicating Sustainability for the Green Economy. New York: M.E.

Mirzayeva, G., Turkay, O., Akbulaev, N., \& Ahmadov, F. 2020. The impact of mega-events on urban sustainable development. Entrepreneurship and Sustainability Issues, 7(3), 1653-1666. https://doi.org/10.9770/jesi.2020.7.3(15)

McCormick, John 2001. Environmental Policy in the European Union. The European Series. Palgrave. 21.

O'Sullivan, Arthur; Sheffrin, Steven M. 2003. Economics: Principles in Action. Upper Saddle River, New Jersey: Pearson Prentice Hall. 314.

Pardo, P. \& Schweitzer, J.P. 2018. A long-term strategy for a European circular economy - setting the course for success. London, UK: Institute for European Environmental Policy.

Positions of Ukraine in the rating of environmental efficiency in 2018. Retrieved from http://edclub.com.ua/analityka/pozyciyi-ukrayiny-vreytyngu-ekologichnoyi-efektyvnosti-u-2018-roci

Report on Green Transformation in Ukraine based on OECD Green Growth Indicators 2016. Ministry of economic development and trade of Ukraine. Retrieved from http://www.green-economies-eap.org/resources/2016_GreenTransformation\%20in\%20Ukraine\%20ENG.pdf

Richards, G. \& Palmer, R. 2010. Eventful cities. Cultural management and urban revitalisation. Oxford: Butterworth-Heinemann

Ross, Richard 2015. The spatial distribution of development in Europe and its underlying sustainability correlations. Applied Geography. 63. 35. https://doi.org/10.1016/j.apgeog.2015.07.009

Sachs, Jeffrey D. 2015. The Age of Sustainable Development. New York: Columbia University Press.

Stankevičius A, Novikovas A., Bakaveckas A., \& Petryshyn O. 2020 EU waste regulation in the context of the circular economy: peculiarities of interaction. Entrepreneurship and Sustainability Issues, 8(2), 533-545. http://doi.org/10.9770/jesi.2020.8.2(32)

Seneca, J.J. \& Tausing M.K. 1984. Environmental Economics, 3rd Edition, Englwood Cliffs, NJ: Prentice-Hall.

Smith, Charles Emrys 2009, Economic Indicators, in Wankel, C. (ed.) Encyclopedia of Business in Today's World . California, USA.

Statistical Yearbook of Ukraine for $\quad 2018$. I.Ye.Verner $\quad$ (Ed.). Retrieved from http://www.ukrstat.gov.ua/druk/publicat/kat_u/2019/zb/11/zb_yearbook_2018_e.pdf

Stavins, R., Wagner, A., Wagner, G. 2003. Interpreting Sustainability in Economic Terms: Dynamic Efficiency Plus Intergenerational Equity. Economics Letters. 79 (3): 339-343. Retrieved from https://doi.org/10.1016/S0165-1765(03)00036-3 . hdl:10419/119677 
INSIGHTS INTO REGIONAL DEVELOPMENT

ISSN 2669-0195 (online) http://jssidoi.org/jesi/

2021 Volume 3 Number 2 (June)

http://doi.org/10.9770/IRD.2021.3.2(3)

Sustainable Development Goals: Ukraine: National Report 2017. Ministry of economic development and trade of Ukraine. Retrieved from http://www.un.org.ua/images/SDGs_NationalReportEN_Web.pdf

The History of Development 2008, 3rd Ed. New York: Zed, 194.

Towards a circular economy: A zero waste program for Europe 2014. European Commission. Retrieved from https://ec.europa.eu/environment/circular-economy/pdf/circular-economy-communication.pdf

Transforming our world: the 2030 Agenda for Sustainable Development. Resolution adopted by the General Assembly United Nations. Retrieved from http://www.un.org.ua/en/publications-and-reports/global-un-publications/4337-transforming-our-world-the-2030-agendafor-sustainable-development-2015

Xingrong Zhao, Xi Zhang, Ning Li, Shuai Shao \& Yong Geng 2017. Decoupling economic growth from carbon dioxide emissions in China: A sectoral factor decomposition analysis. Journal of Cleaner Production, 142, 3500-3516. Retrieved from https://doi.org/10.1016/i.jc lepro.2016.10.117

Yi Li, Jan Degener, Matthew Gaudreau, Yangfan Li \& Martin Kappas 2016. Adaptive capacity-based water quality resilience transformation and policy implications in rapidly urbanizing landscapes. Science of The Total Environment, 569-570, 168-178. Retrieved from https://doi.org/10.1016/j.scitotenv.2016.06.110

\section{Acknowledgements}

The research was performed within the Research work "Dominants of investment and innovation policy of nature management of the national economy "budget program" Support for the development of priority areas of research" (Code of the budget program 6541230).

Andryeyeva Natalya - Doctor of Economics, Professor of Economics, Academician of the Academy of Economic Sciences of Ukraine, Chief Researcher of Institute of Market Problems and Economic\&Ecological Research of NAS of Ukraine, Professor of Marketing, Odessa National University of Economics, Professor of Environmental Economics, Odessa State Ecological University. Her work was awarded for educational and research work by diplomas of the Ministry of Education and Science of Ukraine, the Odessa Regional State Administration and the mayor of Odessa. She is an official international UN expert of UNDP projects in Ukraine (participated in the expert evaluation of the UNDP project "Integration of the provisions of RIE Conventions into the national policy of Ukraine"). Today he is a member of the editorial board: the international Czech journal "European Journal of Economics and Management", the Ukrainian scientific journal "Economics. Ecology. Socium", a collection of scientific papers "Economic Innovations". Research interests: sustainability, green economy and regional development, environmental innovation and investment, strategic and environmental marketing, environmental economics and security.

ORCID ID: orcid.org/0000-0002-9960-559X

Oksana Nikishyna - head of Department of market mechanisms and structures of Institute of Market Problems and Economic\&Ecological Research of NAS of Ukraine, Odessa, Ukraine.

Her methodical developments have received awards as the best works in competitions for innovative projec ts in Ukraine. She currently directs research work «Formation of effective logistics of commodity markets» at the Institute of Market Problems and Economic\&Ecological Research NAS of Ukraine, edits articles for the scientific journal «Food Industry Economi cs», Ukraine. Research interests: theory and practice of commodity markets, regulation and evaluation of the efficiency of commodity markets, market logistics, «green» economy, sustainable reproduction development of a market economy.

ORCID ID: orcid.org/0000-0002-7172-3551 
INSIGHTS INTO REGIONAL DEVELOPMENT

ISSN 2669-0195 (online) http://jssidoi.org/jesi/

2021 Volume 3 Number 2 (June)

http://doi.org/10.9770/IRD.2021.3.2(3)

Borys Burkynskyi is the Doctor of Economics, Professor of Economics, Academician of the National Academy of Sciences of Ukraine, Chief Researcher of Market Mechanisms and Structures Department, Institute of Market Problems and Economic\&Ecological Researches, NAS of Ukraine, Odessa, Ukraine. His scientific works were awarded with prestigious national prizes and awards of Ukraine. He is the editor-in-chief of the scientific collection "Economic Innovations" and the head of the scientific council of the international journal "Economics. Ecology. Society". Research interests: development of commodity markets; property relations for recreational and tourist resources; regional investment policy; "green" economy; environmental economics

ORCID ID: orcid.org/0000-0001-9303-0898

Nina Khumarova is Doctor of Economics, Professor of Economics, the Chief scientist of Nature Use Economic Regulation Department, Scientific Secretary, Institute of Market Problems and Economic\&Ecological Researches, NAS of Ukraine, Odessa, Ukraine. She is the executive secretary of Ukrainian scientific editions' editorial boards "Economic Innovations" and "Food Industry Economics", and reviewer for studies on the sustainable development of the national economy and the nature management economics. Research interests: ecologization of entrepreneurial activity; sustainable use of natural resources; ecological audit and managment; inclusion approaches in nature use managment.

ORCID ID: orcid.org/0000-0001-5255-8004

Oleksandr Laiko is the Doctor of Economics, Senior Researcher, Vice-director for scientific work, Institute of Market Problems and Economic\&Ecological Research NAS of Ukraine, Odessa, Ukraine. His scientific work, dedicated to mechanisms of capital outflow regulation, won awards of the President of Ukraine for young scientists. Results of his research on investment-innovative development of regions in emerging economies were positively appreciated and implemented by OECD (Paris, France). Now he is engaged in preparation of methodology of international and interregional investment flows estimation that is to be sent for evaluation by Global Financial Integrity, USA. Research interests: investments and capital flows, regional development, strategizing of territorial communities development, sustainable investments.

ORCID ID: orcid.org/0000-0001-7082-0862

Hanna Tiutiunnyk is the Candidate of economic sciences, Researcher of Institute of Market Problems and Economic\&Ecological Research NAS of Ukraine, Odessa, Ukraine. Her scientific work was awarded by the Southern Research Center of the National Academy of Sciences of Ukraine and the Ministry of Education and Science of Ukraine, the Department of Education and Science of the Odessa Regional State Administration. Research interests: economic\&organizational provision of formation ecologically safe lands, green economy, inclusive economy, experience economy, sustainable developmemt.

ORCID ID: orcid.org/0000-0003-4864-6129

Make your research more visible, join the Twitter account of INSIGHTS INTO REGIONAL DEVELOPMENT: @IntoInsights

Copyright (C) 2021 by author(s) and VsI Entrepreneurship and Sustainability Center

This work is licensed under the Creative Commons Attribution International License (CC BY).

http://creativecommons.org/licenses/by/4.0/

(c) (i) Open Access 